\title{
Isolasi Jamur Tanah dari Muara Sungai di Desa Kilensari Kecamatan Panarukan Serta Skrining Aktivitas Antibakteri Terhadap Pseudomonas aeruginosa
}

\author{
Amrina Rosyada Fajriyanti, Bawon Triatmoko dan Ari Satia Nugraha* \\ Drug Utilisation and Discovery Research Groups, Fakultas Farmasi, Universitas Jember, Jl. Kalimantan I/2, \\ Jember, Indonesia 68121 \\ *email korespondensi: arisatia@unej.ac.id \\ Received 30 August2020, Accepted 24 June 2021, Published 15 July 2021
}

\begin{abstract}
Abstrak: Kasus infeksi oleh bakteri menjadi sepuluh besar kasus yang mengakibatkan kematian di Indonesia dengan persentase 9,5\%. Penggunaan antibiotik yang tidak tepat untuk mengatasi masalah infeksi dapat menyebabkan resistensi antibakteri. Untuk mengatasi hal tersebut, banyak dilakukan pengembangan terhadap agen-agen antibakteri. Banyak penelitian menunjukkan bahwa aktivitas antibakteri dapat ditemukan pada mikroorganisme dalam tanah. Penelitian ini dilakukan penelusuran dan isolasi fungi tanah muara di Desa Kilensari Kecamatan Panarukan serta skrining aktivitas antibakteri terhadap Pseudomonas aeruginosa yang bertujuan untuk memperoleh kandidat antibakteri yang potensial. Metode yang digunakan dalam penentuan aktivitas antibakteri pada penelitian ini yaitu metode mikrodilusi berdasarkan protokol Clinical and Laboratory Standards Institute tahun 2015. Hasil yang diperoleh dari tahap isolasi yaitu 6 isolat fungi tanah yang diberi kode IS-PN-A1, IS-PN-A2, IS-PN-T1, IS-PN-T2, IS-PN-B1 dan IS-PN-B2. Isolat yang didapatkan dilakukan skrining awal uji aktivitas antibakteri dengan metode ujikontak langsung dengan bakteri Pseudomonas aeruginosa. Zona bening yang terbentuk menunjukkan aktivitas antibakteri dari isolat. Isolat fungi tanah muara kemudian dilakukan proses fermentasi untuk memproduksi metabolit sekunder. Hasil fermentasi di lakukan proses ekstraksi menggunakan etil asetat yang nantinya ekstrak akan digunakan dalam uji aktivitas antibakteri menggunakan metode mikrodilusi. Hasil uji aktivitas antibakteri menunjukkan bahwa fungi tanah muara sungai Desa Kilensari Kecamatan Panarukan memiliki aktivitas antibakteri terhadap bakteri Pseudomonas aeruginosa. Persen penghambatan fungi tanah muara dengan nama isolat IS-PN-A1

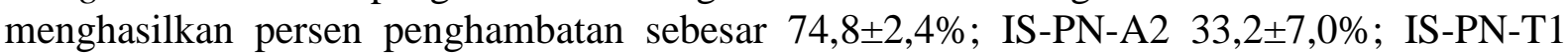

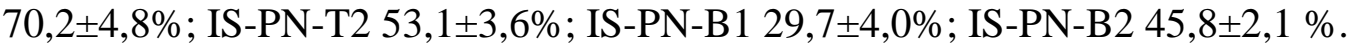

Kata kunci: Fungi Tanah; Antibakteri; Pseudomonas aeruginosa

Abstract. Isolation of soil fungi from estuary in kilensari village district of panarukan and screening of antibacterial activities on Pseudomonas aeruginosa. Infectious cases are becoming a major ten-fold death-causing case In Indonesia with a $9.5 \%$ presentation. Using antibiotics in the wrong way for infectious diseases can cause antibacterial resistance. Many research developments have found a new antibacterial agent to solve these problems. In this research, the search and isolation of soil from the Kilensari village district of Panarukan and the screening activities of Pseudomonas aeruginosa. The method used in determining the antibacterial activity in this study is microdilution based on the Clinical and Laboratory Standards Institute 2015 protocol. The results of this research are six isolates named IS-PNA1, IS-PN-A2, IS-PN-T1, IS-PN-T2, IS-PN-B1, and IS-PN-B2. Isolate then prepared for initial screening by direct contact between the bacteria and the isolate. Clear zone showing the antibacterial activity of the isolate. Isolate the soil fungi and then proceed with fermentation to produce the secondary metabolite. The fermentation results will be extracted using ethyl 
acetate and then used in antibacterial activity tests using the microdilution method. The antibacterial test showed that soil fungi in the Kilensari village of Panarukan had antibacterial activity against Pseudomonas aeruginosa. Percent inhibition of IS-PN-A1 isolate at $74.8 \pm 2.4$

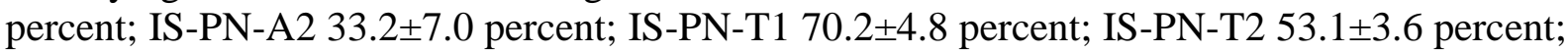
IS-PN-B1 29.7 \pm 4.0 percent; IS-PN-B2 45.8 \pm 2.1 percent.

Keywords: Soil Fungi; Antibacterial; Pseudomonas aeruginosa

\section{Pendahuluan}

Antimicrobial Resistance (AMR) selama beberapa dekade ini menjadi masalah serius dalam dunia kesehatan dan menjadi isu global khususnya pada menurunnya efektifitas pengobatan infeksi yang disebabkan oleh mikroba seperti jamur, bakteri dan virus. Organisasi kesehatan dunia yaitu WHO mengestimasikan sebanyak 700.000 orang akan meninggal setiap tahunnya akibat resistensi antibiotik(2014). Sedangkan pada tahun 2050 diperkirakan sekitar 10 juta orang terancam meninggal disebabkan oleh resistensi antimikroba (O’Neill, 2016). Kasus-kasus resistensi antimikroba khususnya pada resistensi antibakteri terjadi dikarenakan penggunaan antibiotik yang tidak sesuai pada kasus infeksi.

Kasus infeksi oleh bakteri menjadi sepuluh besar kasus yang mengakibatkan kematian dengan persentase 9,5\%di Indonesia (WHO, 2014). Kementerian Kesehatan Republik Indonesia dalam laporan data dan profil kesehatan Indonesia tahun 2018 melaporkan angka kejadian kasus infeksi yang tinggi mencapai angka total sebanyak 1.249.958 kasus (Kemeterian Kesehatan RI, 2018). Laporan yang berjudul Antimicrobial Resistence: Global Report on Surveillance menunjukkan bahwa Asia Tenggara memiliki angka tertinggi dalam kasus kejadian resistensi mikroba. (WHO, 2014). Pengembangan antibakteri baru untuk menunjang antibakteri yang menjadi tidak efektif, membawa urgensi untuk memenuhi kebutuhan pengobatan yang manjur terhadap penyakit infeksi.

Sumber agen antibakteri dapat diperoleh dari dalam tanah (Taylor et al., 2009). Tanah menjadi tempat yang baik untuk mikroba penghasil agen antibakteri dikarenakan persaingan nutrisi dan wilayah yang kuat (Karwehl \& Stadler, 2016). Skrining antibiotik dari mikroorganisme tanah telah dilakukan sejak 60 tahun yang lalu dan menunjukkan persentase yang tinggi terhadap metabolit sekunder yang dihasilkan fungi tanah. Terdapat sekitar 23.000 metabolit sekunder, $42 \%$ dihasilkan dari Actinobacteria, 42\% dari fungi dan $16 \%$ dari bakteri lainnya (Srividya et al., 2008).

Fungi yang menghasilkan aktivitas antibakteri yang menjanjikan sebagai sumber antibiotik baru dapat diisolasi dari tanah hutan Kubah National Park Malaysia (Wibowo et al., 2017). Tanah muara juga menjadi sumber fungi yang dapat diisolasi seperti pada penelitianyang dilakukan terhadap sedimen muara sungai dimana telah menghasilkan beberapa isolat fungi yang berpotensi sebagai sumber antibiotik (Khandavilli et al., 2016). 
Muara sungai merupakan ekosistem yang masih dipengaruhi oleh ekosistem laut seperti pasang surut, gelombang dan aliran air tawar serta sedimen muara sungai.

Eksplorasi yang lebih luas terhadap kekayaan fungi tanah muara sungai bertujuan untuk penelusuran sehingga memperoleh kandidat antibakteri yang potensial. Sampel tanah yang digunakan untuk isolasi fungi tanah dalam penelitian ini yaitu tanah muara sungai di Desa Kilensari Kecamatan Panarukan Kabupaten Situbondo. Pemilihan kawasan didasarkan pada studi awal potensi fungi tanah di beberapa tempat seperti kawasan Sidoarjo, Situbondo, Madura dan Banyuwangi yang telah dilakukan sebelumnya menunjukkan daerah Situbondo mempunyai potensi fungi tanah yang memiliki aktivitas antibakteri (Pamungkas, 2021) sehingga dilakukan penyusuran yang lebih luas lagi di kawasan Situbondo. Penelitian ini menggunakan metodeMicrodilution method untuk pengujian aktivitas antibakteri karena merupakan metode yang dapat mengukur secara kuantitatif nilai penghambatan bakteri selain itu juga sensitif dan cepat.

\section{Bahan dan Metode}

Tanah muara sungai yang diperoleh dari Desa Kilensari Kecamatan Panarukan Kabupaten Situbondo Jawa timur, Air Laut dari pantai pasir putih Situbondo, Laminar Air Flow (THERMO CIENTIFIC 1300 SERIES A2), autoclave (B-ONE), shaker incubator (BONE), neraca analitik (OHAUS), hot plate (HEIDOLPH), vortex (GENE-2), mikropipet (Socorex dan Eppendorf), centrifuge, spektrofotometer UV-Vis (GENESYS), microplate flat bottom 96 wells (IWAKI), microplate reader (HumaReader HS), lemari asam, ultraviolet detektor, destilator. aqua demineralisata (HYDROBATT), air laut, larutan $\mathrm{NaCl}$ 0,9\%, Potato Dextrose Agar (PDA) (HIMEDIA), Potato Dextrose Broth (PDB) (HIMEDIA), Mueller Hinton Agar (MHA) (Merck), Mueller Hinton Broth (MHB) (HIMEDIA), bakteri Staphylococcus aureus ATCC 6538 , DMSO (Emsure), $\mathrm{CaCl}_{2}$ (Sigma), $\mathrm{MgCl}_{2}$ (Brataco), $\mathrm{BaCl}_{2}, \mathrm{H}_{2} \mathrm{SO}_{4}$, etil asetat teknis, gentamisin sulfat, lempeng kromatografi lapis tipis silika gel $\mathrm{F}_{254}$, reagen Dragendorff, uap amonia, $\mathrm{FeCl}_{3}$, vanilin- $\mathrm{H}_{2} \mathrm{SO}_{4}$, metanol pa (Emsure), dikloromotana pa (Emsure).

\subsection{Preparasi sampel tanah}

Pengambilan sampel tanah muara dengan menggunakan pipa untuk mendapatkan tanah bagian atas $(5 \mathrm{~cm}$ tanah yang terambil pada bagian atas pipa), bawah ( $5 \mathrm{~cm}$ tanah terbawah pada pipa) dan tengah (tanah ditengah tengah pipa). Sampel tanah sungai yang didapat ditimbang $10 \mathrm{~g}$ kemudian dimasukkan ke tube dan ditambahkan aquadest steril melalui spuit injeksi. Sampel kemudian dihomogenkan dengan cara divortex yang setelah itu di sentrifugasi dengan kecepatan 500 rpm selama 10 menit. 


\subsection{Pembiakan fungi tanah}

Campuran sampel tanah yang telah memisah diambil supernatannya sebanyak $100 \mu \mathrm{L}$ secara aseptis menggunakan mikropipet. Sampel kemudian dipindahkan ke atas media Potato Dextrose Agar (PDA) dan diratakan menggunakan spreader. Inkubasi dilakukan pada suhu ruangan $28 \pm 2^{\circ} \mathrm{C}$ selama 7 hari.

\subsection{Isolasi dan pemurnian fungi tanah}

Isolasi fungi tanah muara sungai diawali dengan melakukan pengamatan terhadap koloni fungi yang tumbuh, diamati berdasarkan perbedaan morfologinya dari bentuk maupun warnanya. Fungi tanah muara yang mempunyai perbedaan morfologi dipisahkan dengan cara diambil menggunakan ose lalu masing-masing dipindahkan ke media Potato Dextrose Agar (PDA) yang baru.

\subsection{Skrining awal aktivitas antibakteri}

Skrining dilakukan dengan metode uji kontak langsung atau uji antagonis fungi dengan bakteri uji. Potongan isolat fungi dengan diameter $1 \mathrm{~cm}$ ditempelkan pada media Muller Hinton Agar (MHA) yang sebelumnya sudah dilakukan kultur bakteri uji dengan cara bakteri dipipet sebanyak $100 \mu \mathrm{L}$ dan diratakan dengan spreader pada media MHA. Uji antagonis fungi dan bakteri uji diinkubasi pada suhu $37^{\circ} \mathrm{C}$ selama $18-24$ jam.

\subsection{Fermentasi}

Fermentasi dilakukan dengan memasukkan potongan isolat berdiameter $0,9 \mathrm{~cm}$ ke dalam media Potato Dextrose Broth (PDB) sebanyak $200 \mathrm{~mL}$. Inkubasi dilakukan pada suhu $28^{\circ} \mathrm{C}$ selama 14 hari sampai fungi tanah dengan kecepatan agitasi 125 rotasi per menit sampai mencapai fase stationer.

\subsection{Ekstraksi}

Proses ekstraksi dilakukan dengan menambahkan etil asetat pada media hasil fermentasi dengan perbandingan 1:1 dan dilakukan sebanyak 2-3 kali partisi. Hasil ekstraksi dikumpulkan dan etil asetat kemudian diuapkan dalam lemari asam hingga. Hasil ekstraksi setelah penguapan kemudian ditimbang bobotnya dan disimpan.

\subsection{Uji aktivitas antibakteri}

Uji Aktivitas Antibakteri dilakukan dengan mengacu pada protokol standar Clinical and Laboratory Standart Institute (CLSI)(CLSI, 2015) menggunakan konsentrasi tunggal yaitu $100 \mu \mathrm{g} / \mathrm{ml}$.

\subsection{Skrining fitokimia}

Skrining fitokimia dilakukan dengan metode KLT dilanjutkan dengan perekasi warna. Larutan ekstrak (1 mg/mL) ditotolkan pada lempeng KLT $(20 \mu \mathrm{L})$ kemudian dieluasi 
menggunakan eluen campuran diklorometan: methanol (9:1). Lempengan KLT kemudian direasikan dengan reagen dragendorff untuk deteksi alkaloid yang akan menghasilkan noda berwarna jingga, uap ammonia untuk mendeteksi flavonoid yang akan menghasilkan noda berwarna kuning intensif, $\mathrm{FeCl}_{3}$ untuk deteksi polifenol akan membentuk noda berwarna hitam, vanillin asam sulfat untuk mendeteksi terpenoid dan fenolat akan menghasilkan warna ungu-merah muda.

\subsection{Analisis data}

Hasil percobaan uji aktivitas antibakteri ekstrak etil asetat hasil fermentasi isolat fungi tanah terhadap Staphylococcus aureus dengan metode mikrodilusi akan didapatkan data absorbansi. Dari hasil pengukuran absorbansi penghambatan pertumbuhan bakteri dapat dihitung persamaan 1 .

$$
\% \text { penghambatan }=\left(1-\frac{(A b s C-A b s D)}{(A b s A-A b s B)}\right) \times 100 \%
$$

Persamaan 1. Rumus pengukuran absorbansi penghambatan pertumbuhan bakteri. Absorbansi (abs); kontrol negatif ekstrak/gentamisin (A); kontrol DMSO $1 \%$ atau media CAMHB (B); larutan uji ekstrak/gentamisin (C); kontrol ekstrak/gentamisin (D).

\section{Hasil dan Pembahasan}

\subsection{Pembiakan fungi tanah}

Pembiakan fungi tanah dilakukan pada sampel tanah yang diambil pada bagian atas, tengah dan bawah yang bertujuan untuk melihat perbedaan jenis, jumlah dan aktivitas antibakteri fungi tanah berdasarkan kedalaman tanah. Koloni yang tumbuh dari sampel tanah yang diambil dari bagian atas, tengah dan bawah pipa penyimpan sampel tanah (Gambar 1). Beberapa koloni mempunyai bentuk yang berfilamen dan irregular, memiliki warna koloni putih dan putih kekuningan dengan permukaan yang halus (Gambar 1). Ciri-ciri koloni tersebut menunjukkan kemiripan antara mikroorganisme yang tumbuh sebagai khamir atau bakteri khususnya aktinomisetes. Namun yang menjadi pembeda koloni sampel tanah muara sungai tersebut mempunyai koloni yang berukuran besar sedangkan jika bakteri mempunyai koloni yang kecil-kecil seperti titik dan cenderung saling terpisah (Sousa et al, 2013). Media yang digunakan yaitu potato dextrose agar yang merupakan media yang banyak digunakan dalam kultur jamur tanah (Watanabe, 2010).

\subsection{Isolasi dan pemurnian fungi tanah}

Isolasi dan pemurnian fungi tanah dilakukan untuk pengamatan secara morfologi biakan koloni yang tumbuh dalam media PDA. Terdapat 6 isolat yang diambil dari sampel tanah bagian atas, tengah dan bawah (Gambar 2). Isolat diberi kode nama IS-PN-A1 (A) diambil dari biakan koloni fungi berwarna putih sedangkan IS-PN-A2 (B) diambil dari biakan koloni 
fungi berwarna putih kekuningan. Isolat yang diberi kode IS-PN-T1 (C) diambil dari koloni dengan warna putih kekuningan, permukaan yang tipis dan halus serta koloni yang berbentuk irregular. IS-PN-T2 (D) diambil dari koloni berwarna putih dan mempunyai permukaan lebih tebal serta koloni nya berbentuk filamen. Isolat yang diberi kode IS-PN-B1 (E) diambil dari koloni berwarna putih sedangkan IS-PN-B2 (F) diambil dari koloni yang berwarna kuning kecoklatan.
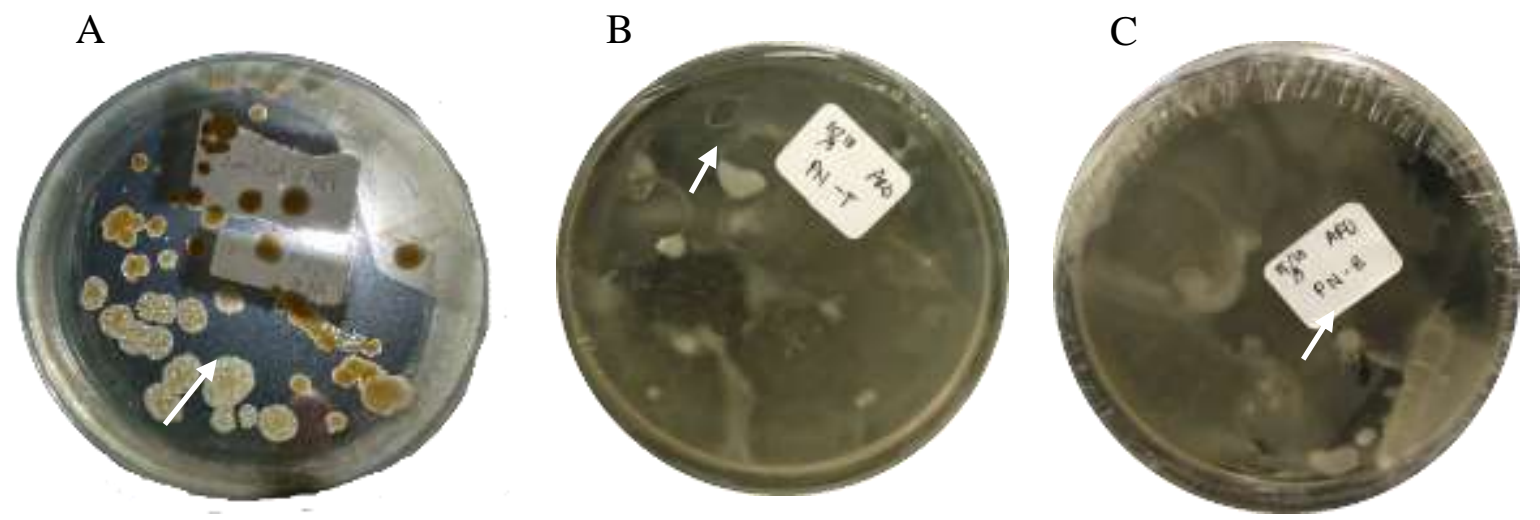

Gambar 1. Biakan fungi tanah muara sungai sampel tanah bagian atas (A), tengah (B), bawah (C) dari pipa penyimpanan sampel tanah yang dibiakkan selama 7 hari pada media PDA.Tanda panah menunjukkan bentuk filamen pada biakan fungi tanah A sedangkan bentuk irregular pada biakan fungi tanah B dan C.
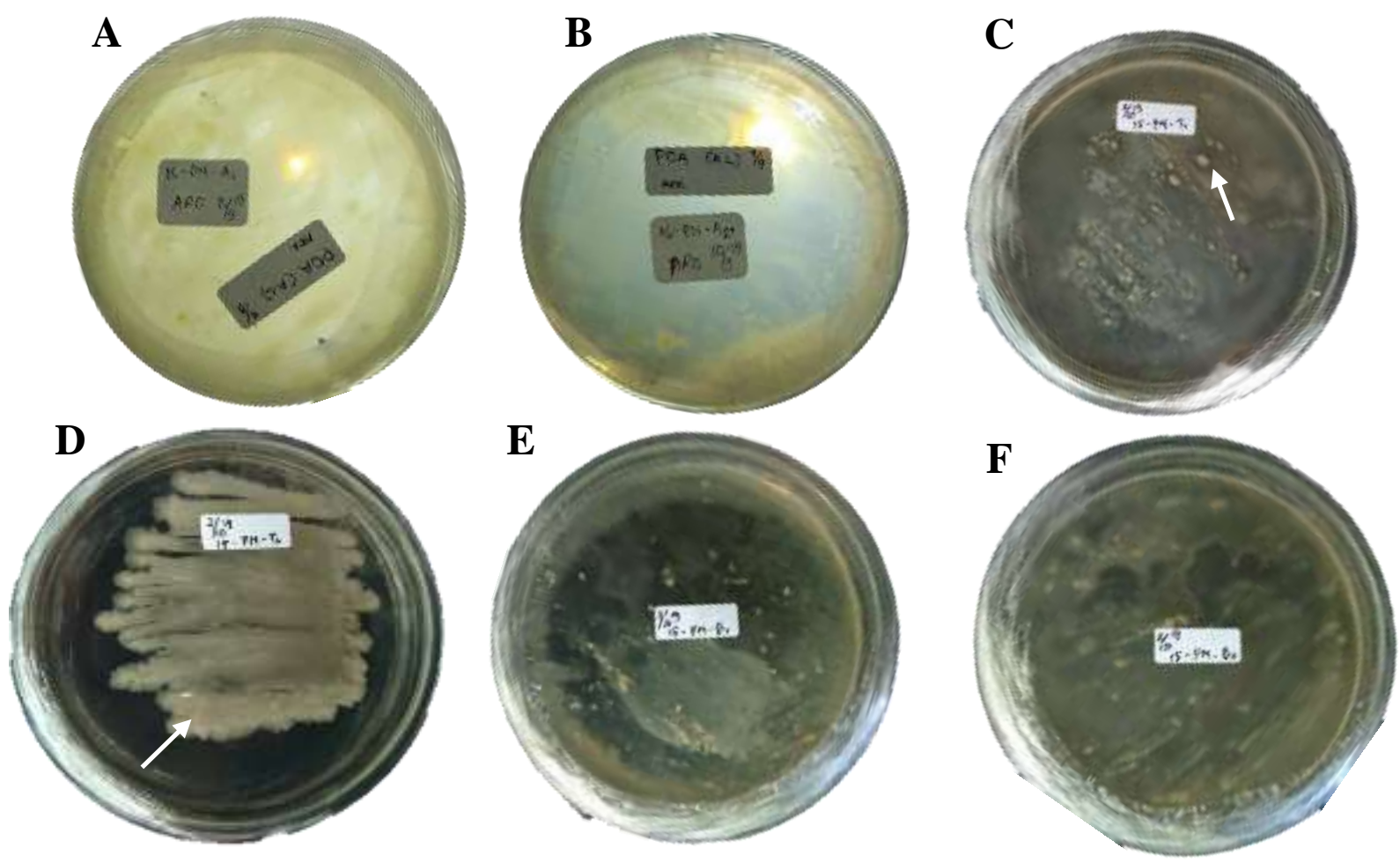

Gambar 2. Isolat fungi tanah muara IS-PN-A1 (A), IS-PN-A2 (B), IS-PN-T1 (C),IS-PN-T2 (D), IS-PN-B1 (E), IS-PN-T2 (F) satu kali proses pemurnian. Biakan fungi tanah $\mathrm{D}$ menunjukkan bentuk filamen sedangkan biakan fungi tanah lainnya berbentuk irregular. 
Pengamatan secara mikroskopis bertujuan untuk melihat morfologi sel biakan fungi tanah. Hasil pengamatan secara mikroskopis pada 6 isolat fungi tanah dapat dilihat pada Gambar 3. Morfologi sel yang tumbuh berbentuk bulat juga beberapa berbentuk oval dengan inti sel ditengahnya. Mikroorganisme yang menunjukkan ciri-ciri dengan sel berbentuk bulat yaitu fungi jenis khamir dan bakteri dengan famili aktinomisetes. Khamir merupakan mikroorganisme eukariotik uniseluler yang secara mikroskopis dapat dilihat berupa sel bulat atau berbentuk oval seperti telur dengan inti ditengahnya (Sabdaningsih, 2016) sedangkan bakteri merupakan mikroorganisme prokariotik dengan sel berbentuk bulat atau oval namun tidak memiliki inti sel (Pepper \& Gentry, 2015). Untuk memastikan spesies dari fungi tersebut perlu dilakukan identifikasi filogenetik lebih lanjut menggunakan metode PCR ( LoBuglioet al, 1995).
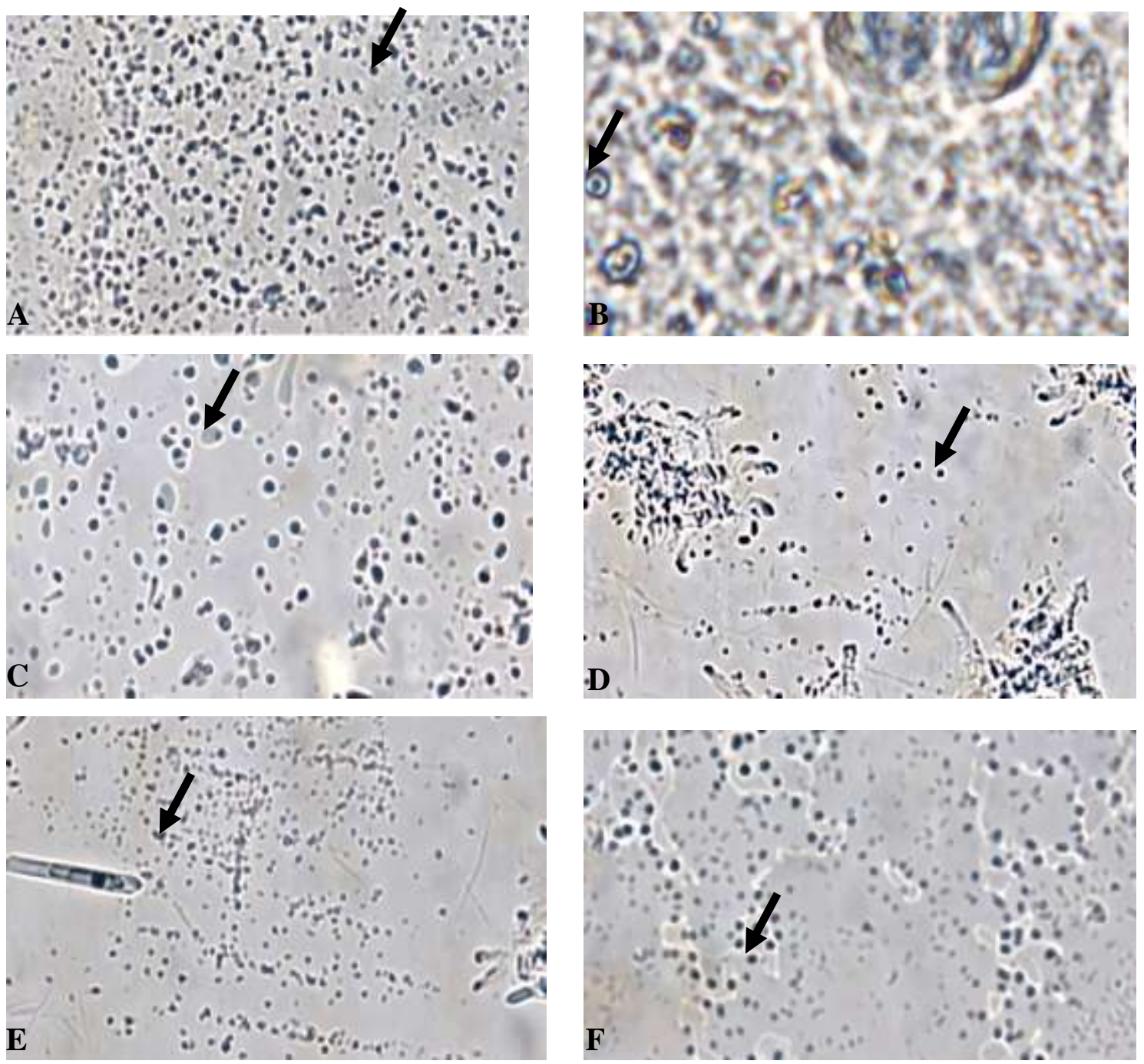

Gambar 3. Hasil mikroskopis isolat IS-PN-A1 (A), IS-PN-A2 (B), IS-PN-T1 (C), IS-PN-T2 (D), ISPN B1 (E), IS-PN-B2(F) dengan perbesaran 400x.Tanda panah menunjukkan sel yang berbentuk bulat dengan inti sel ditengah. 


\subsection{Skrining aktivitas antibakteri}

Skrining aktivitas antibakteri bertujuan untuk mengetahui isolat yang mempunyai potensi penghambatan pertumbuhan bakteri. Skrining aktivitas antibakteri dilakukan dengan mengamati zona bening yang terbentuk setelah uji kontak langsung antara isolat dengan bakteri Pseudomonas aeruginosa.Metode ini telah banyak digunakan untuk mengetahui potensi aktivitas antibakteri yang dihasilkan fungi tanah (Balouiri et al, 2016). Ekstrak fungi akan memberikan aktivitas yang lebih besar daripada isolat fungi yang dikontakkan langsung dengan bakteri (Sara Ramírez et al., 2015). Hasil yang didapatkan dari uji kontak langsung ditunjukkan dalam Gambar 4 dimanaisolat IS-PN-A1, IS-PN-A2, IS-PN-T1, IS-PN-T2, ISPN-B1, IS-PN-B2 menunjukkan adanya hambatan berupa diameter zona bening yang terbentuk pada keseluruhan isolat.

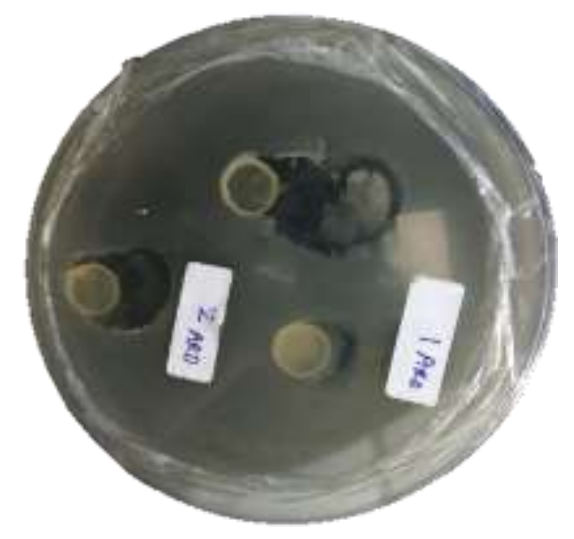

A

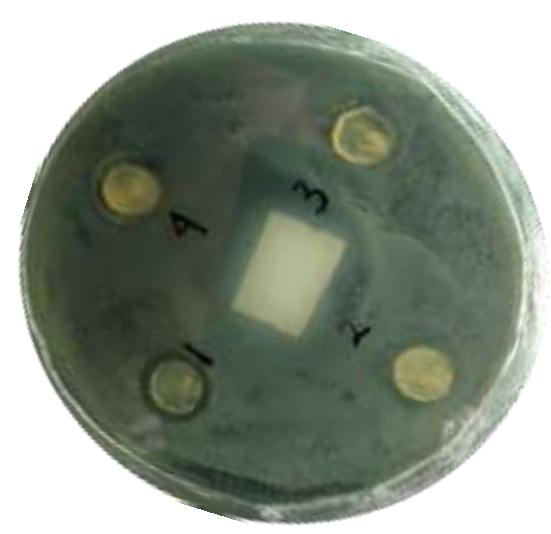

B

Gambar 4. Gambar hasil uji kontak isolat IS-PN A1, IS-PN-A2 (A) dan IS-PN-T1, IS-PNT2, IS-PN-B1, IS-PN-B2 (B) yang menunjukkan adanya zona bening pada semua isolat yang diuji kontak.

\subsection{Uji aktivitas antibakteri}

Pengujian ini menggunakan metode mikrodilusi untuk mengetahui persen penghambatan pertumbuhan bakteri Pseudomonas aeruginosa. Ekstrak fungi tanah yang diuji dengan metode mikrodilusi pada percobaan ini dilakukan menggunakan konsentrasi tunggal yaitu $100 \mu \mathrm{g} / \mathrm{mL}$. Persen penghambatan gentamisin menunjukkan nilai rata-rata konsentrasi gentamisin sebesar 99,7 $\pm 0,1 \%$ (Tabel 1). Persen penghambatan yang di persyaratkan untuk konsentrasi gentamisin 0,5-2 $\mu \mathrm{g} / \mathrm{mL}$ yaitu $\geqslant 80 \%$ (CLSI, 2015). Berdasarkan hasil yang didapatkan, metode mikrodilusi dalam pengujian aktivitas antibakteri ekstrak fungi tanah dikatakan baik karena kontrol positif yang digunakan yaitu gentamisin memenuhi persyaratan CLSI.

Kosolven yang digunakan untuk membantu melarutkan ekstrak yaitu DMSO karena merupakan kosolven yang dapat melarutkan senyawa polar dan non polar (Kirkwood et al, 
2018). Konsentrasi DMSO yang digunakan yaitu $1 \%$ jika menggunakan konsentrasi lebih dari 1\% dikhawatirkan akan menghasilkan positif palsu karena DMSO juga dapat menghambat pertumbuhan bakteri (Kirkwood et al, 2018). Kontrol DMSO dipakai untuk memastikan bahwa kosolven yang digunakan tidak mempengaruhi aktivitas ekstrak dalam menghambat pertumbuhan bakteri. Tabel 1 (Persen penghambatan DMSO) menunjukkan bahwa DMSO tidak mempengaruhi penghambatan pertumbuhan bakteri karna persen penghambatan yang didapatkan hanya $0,8 \pm 0,2 \%$ Sehingga dapat dipastikan bahwa penggunaan DMSO $1 \%$ tidak akan menghasilkan aktivitas yang bersifat positif palsu.

Media yang digunakan adalah CAMHB yang direkomendasikan oleh CLSI agar kadar kation $\mathrm{Mg}^{2+}$ dan $\mathrm{Ca}^{2+}$ dalam media Mueller Hinton bisa terstandar karena media MHB yang beredar seringkali memiliki kadar kation $\mathrm{Mg}^{2+}$ dan $\mathrm{Ca}^{2+}$ yang berbeda. Apabila terdapat perbedaan kation tersebut akan berpengaruh pada aktivitas agen antibakteri karena kation tersebut mempengaruhi integritas membran sel bakteri sehingga standarisasi kation menjadi penting untuk dilakukan (Ramirez-Ronda, et al, 1975).

Tabel 1. Persen penghambatan ekstrak fungi tanah diisolasi dari muara sungai Desa Kilensari terhadap bakteri $P$. aeruginosa.

\begin{tabular}{|c|c|c|c|c|c|c|c|c|}
\hline \multirow[b]{2}{*}{ Replikasi } & \multirow{2}{*}{$\begin{array}{c}\text { Persen } \\
\text { Penghambatan } \\
\text { Gentamisin } \\
(\%)\end{array}$} & \multirow{2}{*}{$\begin{array}{c}\text { Persen } \\
\text { Penghambatan } \\
\text { DMSO }(\%)\end{array}$} & \multicolumn{6}{|c|}{$\begin{array}{c}\text { Persen Penghambatan } \\
\text { Ekstrak Fungi Tanah }(\%)\end{array}$} \\
\hline & & & $\begin{array}{l}\text { IS- } \\
\text { PN } \\
-A 1 \\
\end{array}$ & $\begin{array}{c}\text { IS- } \\
\text { PN- } \\
\text { A2 } \\
\end{array}$ & $\begin{array}{c}\text { IS- } \\
\text { PN- } \\
\text { T1 } \\
\end{array}$ & $\begin{array}{l}\text { IS- } \\
\text { PN- } \\
\text { T2 }\end{array}$ & $\begin{array}{c}\text { IS- } \\
\text { PN- } \\
\text { B1 } \\
\end{array}$ & $\begin{array}{l}\text { IS- } \\
\text { PN- } \\
\text { B2 }\end{array}$ \\
\hline 1 & 99,6 & 1,0 & & & & & & \\
\hline 2 & 99,7 & 0,7 & 74 & 33,2 & 70,2 & 53,1 & 29,7 & 45,8 \\
\hline 3 & 99,8 & 0,8 & $8 \pm$ & $\pm 7,0$ & $\pm 4,8$ & $\pm 3,6$ & $\pm 4,0$ & $\pm 2,1$ \\
\hline Rata-Rata & 99,7 & 0,8 & 2,4 & & & & & \\
\hline SD & 0,1 & 0,2 & & & & & & \\
\hline
\end{tabular}

Uji aktivitas antibakteri ini menunjukkan bahwa ekstrak fungi tanah memiliki aktivitas penghambatan pertumbuhan bakteri Pseudomonas aeruginosa. Persen penghambatan yang dihasilkan masing-masing ekstrak fungi tanahditunjukkan oleh Tabel 1. Persen penghambatan terbesar dihasilkan oleh ekstrak fungi tanah IS-PN-A1 dengan nilai sebesar 74,8 $\pm 2,4 \%$ sedangkan nilai persen penghambatan terkecil dihasilkan ekstrak fungi tanah IS-PN-B1 dengan nilai sebesar $29,7 \pm 4,0 \%$. Persen penghambatan masing- masing ekstrak dengan kontrol positif gentamisin ditunjukkan pada Gambar 5. Persen pengambatan isolat terhadap bakteri uji menghasilkannilai dibawah persen penghambatan gentamisin terhadap bakteri uji. Penelitian sebelumnyamenggunakan metode uji antibakteri difusi cakram dengan konsentrasi adalah1000 $\mu \mathrm{g} / \mathrm{mL}, 2000 \mu \mathrm{g} / \mathrm{mL}, 4000 \mu \mathrm{g} / \mathrm{mL}, 6000 \mu \mathrm{g} / \mathrm{mL}, 8000 \mu \mathrm{g} / \mathrm{mL}$ menghasilkan ratarata zona hambat yaitu 6,$43 ; 7,13 ; 8,17 ; 9,40 ; 11,40$ milimeter (Pamungkas, 2021). 
Penelitian sebelumnya menunjukkan banyak mikoorganisme tanah yang mempuyai aktivitas dalam menghambat pertumbuhan bakteri. Isolasi jamur terhadap beberapa sampel tanah yang diambil dari 5 lokasi berbeda di India menghasilkan 65 isolat. Diketahui 80\% dari jumlah isolat yang diperoleh mempunyai aktivitas antibakteri (Thakur et al, 2007). Screening aktivitas antibakteri fungi tanah juga dilkakukan di Brazil. Hasil yang didapatkan yaitu sebanyak 67\% ekstrak fungi tanah dari 200 isolat mempunyai aktivitas antibakteri (Takahashi et al, 2008). Penelitian ini juga membuktikan bahwa terdapat potensi aktivitas fungi tanah muara sungai yang potensial. Perbedaan persen penghambatan yang diperoleh dari masingmasing isolat menunjukkan bahwa terdapat kemungkinan senyawa yang berbeda dalam suatu golongan senyawa tertentu yang terdapat dalam fungi tanah muara dan berperan sebagai agen antibakteri. Alkaloid juga merupakan golongan senyawa yang dapat ditemukan dalam isolat fungi tanah yang memiliki aktivitas antibakteri (Pamungkas, 2021). Bikaverin merupakan salahsatu senyawa yang berperan sebagai agen atibakteri. Senyawa tersebut didapatkan dari isolat fungi dengan spesies Fusarium sp (Deshmukh et al, 2014). Spesies Penicillium juga diperoleh dari hasil isolasi tanah daerah Cerrado, Brazil. Isolat tersebut menunjukkan adanya aktivitas antibakteri yang tinggi pada senyawa metabolit sekunder yang didapatkan yaitu 6acetyl-4-methoxy-5,7,8- trihydroxynaphthalene-2-carboxylate (Petit et al , 2009). Fungi dengan spesies Aspergillus terreus yang diisolasi dari tanah di Ecuador, Chile menghasilkan 3 metabolit sekunder yang mempunyai aktivitas sebagai agen antibakteri. Diantaranya adalah terreic acid dan butyrolactone (Cazar et al, 2005).

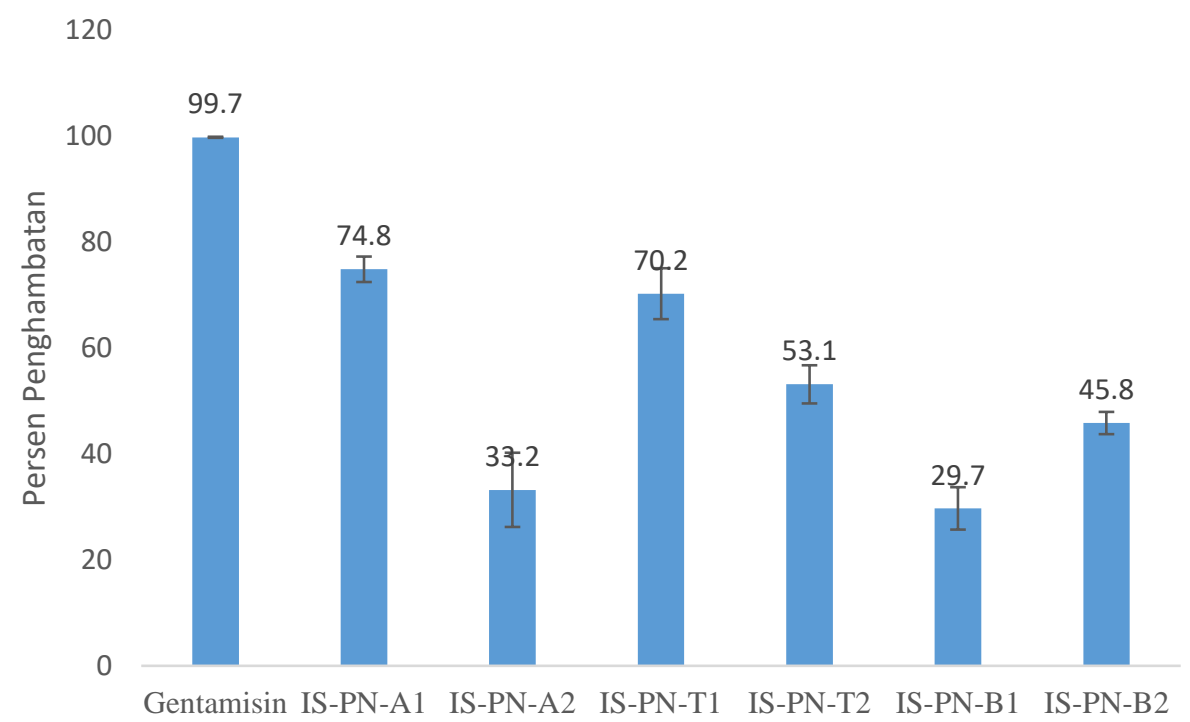

Gambar 5. Persen penghambatan masing-masing ekstrak dan gentamisin terhadap bakteri Pseudomonas aeruginosa yang dianalisis secara statistik. 


\subsection{Skrining fitokimia}

Skrining fitokimia digunakan untuk mengetahui golongan senyawa aktif yang terkandung dalam esktrak. Pada penelitian sebelumnya yang dilakukan uji aktivitas antibakteri pada ekstrak daun anyang-anyang menunjukkan hasil positif mengandung senyawa terpenoid karena terdapat noda berwana ungu (Savitri, 2020) sedangkan penelitian yang dilakukan pada ekstrak tanaman senggugu diketahuiaktivitas antibakteri yang paling baik dicapai oleh fraksi n-heksana dengan kandungan steroid dan terpenoid (Maulana, 2020). Dalam penelitian ini, profil kromatogram menunjukkan rata-rata dua noda pada masing masing esktrak, kecuali esktrak IS-PN-A2 tidak muncul noda (Gambar 6). Senyawa mayor pada Rf 0.45 dan 0.55 muncul pada semua esktrak, kecuali IS-PN-A2. Senyawa yang lebih polar pada Rf 0.20 dan 0.25 hanya muncul pada ekstrak dengan kode ISPN B1, IS-PN-B2.

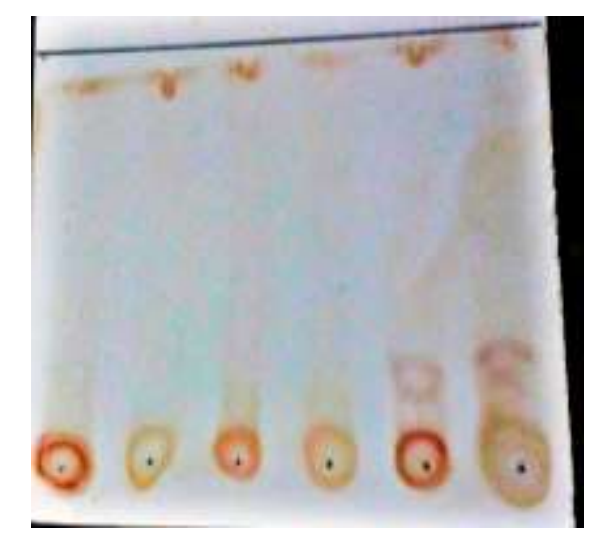

A

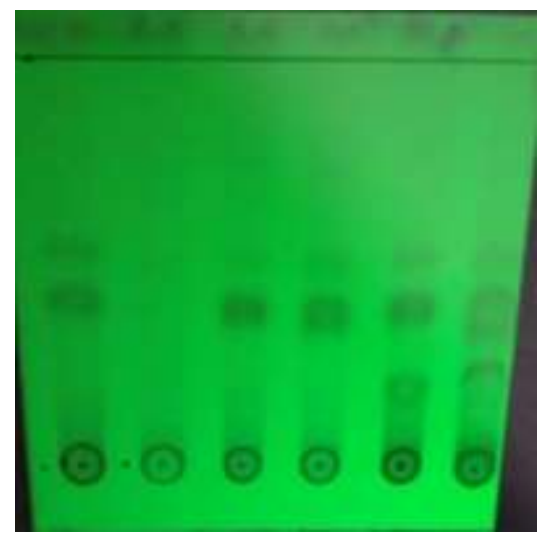

B

Gambar 6. Profil kromatogram ekstrak fungi tanah (dari kiri ke kanan, IS-PN-A1, IS-PN-A2, IS-PN-T1, IS-PN-T2, ISPN B1, IS-PN-B2). Eluen pengembang berupa diklorometan: methanol (9: 1), visualisasi dibawah sinar UV $254 \mathrm{~nm}$ (A) dan dengan reagen semprot vanillin asam sulfat setelah dilakukan pemanasan (B).

Hasil deteksi senyawa menggunakan reagen semprot dirangkum dalam Tabel 2. Dari semua reagen yang digunakan, hanya reagen vanillin-asam sulfat yang menghasilkan warna deteksi yang positif berupa merah-ungu (Gambar 6). Warna merah-ungu ditunjukkan pada esktrak ISPN B1 (noda dengan Rf 0.20) IS-PN-B2 (noda dengan Rf 0.25). Golongan senyawa terpenoid yang mungkin ditemukan dalam isolat fungi tanah dapat memiliki mekanisme sebagai bakterisidal maupun bakteriostatik (Mahizan et al, 2019).

Tabel 2. Hasil identifikasi ekstrak fungi tanah diisolasi dari muara sungai Desa Kilensari dengan pereaksi warna.

\begin{tabular}{ccc}
\hline Jenis Identifikasi & Pereaksi & Hasil (warna noda) \\
\hline Alkaloid & Dragendorff"s reagent & - \\
Fenol & $\mathrm{FeCl}_{3}$ & - \\
Terpenoid & Vanilin Asam Sulfat & + (merah muda) \\
Flavonoid & Uap Amonia & - \\
\hline
\end{tabular}




\section{Kesimpulan}

Penelitian yang telah dilakukan menyimpulkan baik pengamatan secara makroskopis maupun mikroskopis bahwa mikroorganisme yang tumbuh yaitu fungi dengan jenis khamir. Fungi tanah muara sungai Desa Kilensari Kecamatan Panarukan memiliki aktivitas antibakteri terhadap bakteri Pseudomonas aeruginosa. Fungi tanah muara dengan nama isolat IS-PN-A1

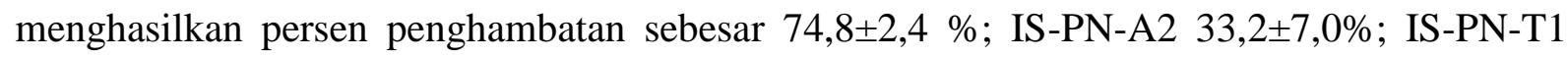

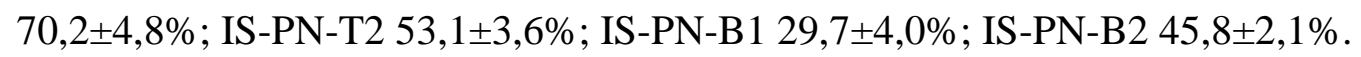

\section{Ucapan Terimakasih}

Penulis mengucapkan terimakasih kepada Universitas Jember atas dukungan fasilitas penelitian.

\section{Deklarasi Konflik Kepentingan}

Semua penulis menyatakan tidak ada konflik kepentingan terhadap naskah ini.

\section{Daftar Pustaka}

Balouiri, M., Sadiki, M., dan Ibnsouda, S. K. (2016). Methods for in vitro evaluating antimicrobial activity: A review. Journal of Pharmaceutical Analysis, 6(2): pp.71-79. 10.1016/j.jpha.2015.11.005

Cazar, M. E., Schmeda-Hirschmann, G., dan Astudillo, L. (2005). Antimicrobial butyrolactone I derivatives from the Ecuadorian soil fungus Aspergillus terreus Thorn. var terreus. World Journal of Microbiology and Biotechnology, 21(6): pp.10671075.10.1007/s11274-004-8150-5

Clinical and laboratory standards Institute (CLSI), (2015), Methods for Dilution Antimicrobial Susceptibility Test for Bacteria that Grow Aerobically, 10 Edition, Wayne : CLSI supplement M07-A10.USA.

Deshmukh, R., Mathew, A., \& Purohit, H. J. (2014). Characterization of antibacterial activity of bikaverin from Fusarium sp. HKF15. Journal of Bioscience and Bioengineering, 117(4): pp.443-448. 10.1016/j.jbiosc.2013.09.017

Karwehl, S., dan Stadler, M. (2016). Exploitation of Fungal Biodiversity for Discovery of Novel Antibiotics. Current Topics in Microbiology and Immunology, 398: pp.303-338. 10.1007/82_2016_496.

Kementerian Kesehatan RI. (2018). Data dan Informasi Profil Kesehatan Indonesia. Kementerian Kesehatan RI, Jakarta, Indonesia.

Khandavilli, R., Meena, R., \& Bd, S. (2016). Fungal Phylogenetic Diversity in Estuarine Sediments of Gautami. Current Research in Enviomental \&Apllied Mycology, 6(4): pp.268-276. 10.5943/cream/6/4/4

Kirkwood, Z. I., Millar, B. C., Downey, D. G., dan Moore, J. E. (2018). Antimicrobial effect of dimethyl sulfoxide and N, N-Dimethylformamide on Mycobacterium abscessus: Implications for antimicrobial susceptibility testing. International journal of mycobacteriology, 7(2): pp.134. 10.4103/ijmy.ijmy

LoBuglio, K. F., \& Taylor, J. W. (1995). Phylogeny and PCR identification of the human pathogenic fungus Penicillium marneffei. Journal of clinical microbiology, 33(1), 8589.

Mahizan, N. A., Yang, S. K., Moo, C. L., Song, A. A. L., Chong, C. M., Chong, C. W., Abushelaibi, A., Lim, S.H.E. dan Lai, K. S. (2019). Terpene derivatives as a potential agent against antimicrobial resistance (AMR) pathogens. Molecules, 24(14): pp.2631. 10.3390/molecules24142631 
Maulana, I. A., Triatmoko, B., \& Nugraha, A. S. Skrining Fitokimia dan Uji Aktivitas Antibakteri Ekstrak dan Fraksi Tanaman Senggugu (Rotheca serrata (L.) Steane \& Mabb.) terhadap Pseudomonas aeruginosa. JPSCR: Journal of Pharmaceutical Science and Clinical Research, 5(1), 01-11.

O'Neill, J. (2016). Tackling drug-resistant infections globally: final report and recommendations.https://amr-

review.org/sites/default/files/160518_Final\%20paper_with\%20cover.pdf. [Accessed 23th June 2021].

Pamungkas, F.B, Triatmoko, B., dan Nugraha, A. S.. 2021. Penelusuran Dan Isolasi Fungi Tanah KabupatenSitubondo Serta Skrining Aktivitas Antibakteri terhadap Pseudomonas aeruginosa. Jurnal Kefarmasian Indonesia, 19(1): pp. 73-79. 10.35814/jifi.v19i1.750

Pepper, I. L., dan Gentry, T. J. (2015). Earth Environments.in Pepper, I.L., Gerba, C.P., dan Gentry, T. J. Environmental Microbiology, 59-88. Amsterdam, Elsevier. 10.1016/B9780-12-394626-3.00004-1.

Petit, P., Lucas, E. M., Abreu, L. M., Pfenning, L. H., dan Takahashi, J. A. (2009). Novel antimicrobial secondary metabolites from a Penicillium sp. isolated from Brazilian cerrado soil. Electronic Journal of Biotechnology, 12(4): pp.8-9. 10.2225/vol12-issue4fulltext-9

Ramirez-Ronda, C. H., Holmes, R. K., dan Sanford, J. P. (1975). Effects of divalent cations on binding of aminoglycoside antibiotics to human serum proteins and to bacteria. Antimicrobial Agents and Chemotherapy, 7(3): pp.239-245. 10.1128/aac.7.3.239

Sabdaningsih, A., Radjasa, O. K., Sabdono, A., dan Trianto, A.(2016) Bioprospecting of Fungi Associated with Cladiella sp. as Antibacterial-MDR against Acinetobacter baumannii from Panjang Island Vicinity. IPCB 2016, 123.

Sara Ramírez, R., Arias M., J. D., Bedoya, J. C., Rueda L., E. A., Sánchez, C. Y., \& Granada G., S. D. (2015). Metabolitos producidos por microorganismos antagonistas son capaces de inhibir in vitro los principales patógenos del aguacate. Agronomia Colombiana, 33(1): pp.58-63. 10.15446/agron.colomb.v33n1.48241

Savitri, G. R., Triatmoko, B., \& Nugraha, A. S. (2020). Skrining Fitokimia dan Uji Aktivitas Antibakteri Ekstrak dan Fraksi Tumbuhan Anyang-Anyang (Elaeocarpus grandiflorus JE Smith.) terhadap Escherichia coli. JPSCR: Journal of Pharmaceutical Science and Clinical Research, 5(1), 22-32.

Sousa, A. M., Machado, I., Nicolau, A., dan Pereira, M. O. (2013). Improvements on colony morphology identification towards bacterial profiling. Journal of microbiological methods, 95(3): pp.327-335.10.1016/j.mimet.2013.09.020

Srividya, A. R., Saritha, G. S., dan Suresh, B. (2008). Study of the soil isolates for antimicrobial activity. Indian Journal of Pharmaceutical Sciences, 70(6): pp.812-815. 10.4103/0250-474X.49132

Takahashi, J. A., de Castro, M. M., Souza, G. G., Lucas, E. M., Bracarense, A. A., Abreu, L. M., Marriel, I.E., Oliveira, M.S., Floreano, M.B., dan Oliveira, T. S. (2008). Isolation and screening of fungal species isolated from Brazilian cerrado soil for antibacterial activity against Escherichia coli, Staphylococcus aureus, Salmonella typhimurium, Streptococcus pyogenes and Listeria monocytogenes. Journal de Mycologie Médicale, 18(4): pp.198-204. 10.1016/j.mycmed.2008.08.001

Taylor, P., Pepper, I. L., Gerba, C. P., Newby, D. T., dan Rice, C. W. (2009). Soil : A Public Health Threat or Savior?. Critical Reviews in Environmental Science and Technology, 39(5): pp.416-432.10.1080/10643380701664748

Thakur, D., Yadav, A., Gogoi, B. K., dan Bora, T. C. (2007). Isolation and screening of Streptomyces in soil of protected forest areas from the states of Assam and Tripura, India, for antimicrobial metabolites. Journal de Mycologie Médicale, 17(4): pp.242-249. 10.1016/j.mycmed.2007.08.001 
Watanabe, T. (2010). Pictorial Atlas of Soil and Seed Fungi: Morphologies of Cultured Fungi and Key to Species. New York: CRC Press.

WHO.

Antimicrobial

Resistance. https://apps.who.int/iris/bitstream/handle/10665/112642/9789241564748_eng.pdf?sequ ence $=1$. [Accessed, 23th June 2021].

Wibowo, M. S., Julianti, E., dan Radzali, M. D. (2017). Isolation and antibacterial activity of soil-derived fungi from Taman Botani Negara, Shah Alam, Malaysia.Acta Pharmaceutical Indonesia, 42(1): pp.18-24.

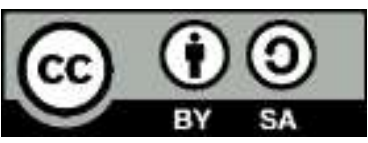

(C) 2021 by the authors. Submitted for possible open access publication under the terms and conditions of the Creative Commons Attribution-ShareAlike 4.0 International (CC BY-SA 4.0) license (https://creativecommons.org/licenses/by-sa/4.0/). 